\title{
Bureaucracy in Higher Education from a Comparative Perspective
}

\author{
Chenqi Liu ${ }^{1, *}$ \\ ${ }^{1}$ School of International Education, Ocean University of China, Qingdao, Shandong 266000, China \\ *Corresponding author. Email: chanky42@126.com
}

\begin{abstract}
This paper aims to examine "bureaucracy" in the higher education context. Contrasting the definitions of bureaucracy in two cultures, it can be seen that the origin of debate started from Weber's rectification of bureaucracy. Since then there were two tributaries - one refers to the original office power explanation and the other refers to organizational structure. Due to disparate political cultures and history of higher education in China and the West, two ways of corresponding to handle the risk of bureaucracy has appeared. The author used empirical example to demonstrate how some higher education systems turn to nepotism for solution. Meanwhile, according to literature review, others seem to search for answers in business management. The author concluded that there exists a risk when the tools are mistaken as goals and solutions are worsening the situation.
\end{abstract}

Keywords: Bureaucracy, Higher education administration, Comparative higher education.

\section{INTRODUCTION}

Even complained by academics around the world, there is still no solution proved to be practical in terms of higher education administration. Bureaucracy has been accused of eroding universities and causing consequences more serious than any other forms of organizations. (Ev) Intellectuals are keen to find a third way that could balance the efficiency and creativity. Many of them borrowed theories from business world, trying to improve the productivity of universities, although the ivory tower seems to be more complicated than the outer side. Especially during this particular and tragic time, when two mainstream social ideologies collide to each other, it provoked conflicting thoughts and minds.

As having been educated that "development always comes from social conflicts", the author believes that from a comparative perspective (China and the West) will help us to discover the essence of "bureaucracy" instead of targeting it as a stress reliving sandbag. The author has searched for "higher education/university/college" and "bureaucracy" as the same time in both English and Chinese academic research engines like CHKI, Springer, Google Scholar etc. However, only very limited results came out, some of which leave the definition of bureaucracy aside while some just tacitly approve of Max Weber's definition and the rest seems to consider Weber as the defender of bureaucracy. Therefore, the author would like to find the origin meaning of bureaucracy and try to excavate its historical and cultural roots. Hopefully, with inadequate experience in both academic and practical world, the author could provide a fresh view to look at the word of "bureaucracy" in higher education system.

\section{ORIGIN - BIRTH OF BUREAUCRACY}

According to Merriam-Webster [1], Bureaucracy comes from the French 'bureaucratie', which was formed by combining bureau ("desk") and -cratie (a suffix denoting a kind of government). Bureaucracy thus originally means office power or office rule, the rule of the officialdom. French economist, Jean Claude Marie Vincent de Gournay was considered to be the person who invented the fourth or fifth form of government under the heading of "bureaucracy." "We have an illness in France which bids fair to play havoc with us; this illness is called bureaumania." The term bureaucracy came into use 
shortly before the French Revolution of 1789, and from there spread rapidly to other countries.

Critical meanings has been shadowing the word since it was born, until Max Weber (1921) redefined bureaucracy in his book Wirtschaft und Gesellschaft [2]. Weber described the "ideal type" bureaucracy in positive terms, considering it to be a more rational and efficient form of organization than the alternatives that preceded it, which he characterized as "charismatic domination" and "traditional domination."

According to Weber, the attributes of modern bureaucracy include its impersonality, concentration of the means of administration, a leveling effect on social and economic differences, and implementation of a system of authority that is practically indestructible, but critical voice has not stopped, Robert K. Merton [3] believed Weber's theory idealized the situation. His essay "Bureaucratic Structure and Personality" (Merton, 1957) describes the "red tape" and other inefficiencies of bureaucracy.

Merton suggested that, if the predominance of rational rules, and their close control of all actions, favors the reliability and predictability of the bureaucrat's behavior, as Weber believed, it could equally lead to his lack of flexibility and his tendency to turn means into ends. Instead of serving as means to an end, these rules become ends in and of themselves [4].

\section{CHINESE CONTEXT}

When it was translated to Chinese, there are two words of it - one matches the original French word — "官僚主义" (Bureaucracy), when "官僚" (bureaucrat) means the government officers or politicians, "主义"(doctrine) is often translated as "lism", indicating a genre of performing. During the long Chinese political history, this kind of bureaucracy roots deeply in its governing culture. From Qin dynasty when the emperor ruled a larger territory than ever before, the governor built a formalized organization and selected bureaucrats as his representatives to manage the country. Hierarchy is the natural choice to run this enormous organization efficiently and to protect his sovereign power. To strengthen his monarch, a rigid societal system has been formed from moral standards to unified measures. Since then, ancient China experienced even more severe bureaucratic governance through every vicissitude of dynasties till the end of feudal period.
The other Chinese word for bureaucracy focuses on Weber's description - " 科层主义 (hierarchism)", which means hierarchical organizational structure. When talking about bureaucracy in higher education, this is the word that has been used often. When search "科层主义 (hierarchism)"and "高等教育(higher education)" on the CNKI, results are much more than 官僚主义 (bureaucracy) and 高等教育(higher education).

In addition, "官僚主义(bureaucracy)" are more used in political subjects, especially in Party Governance. Together with "形式主义(formalism)", "官僚主义(bureaucracy)"carries negative connotation and is detested by people. While "科层主义 (hierarchism)" is more like a neutral term, but some would argue that "科层主义(hierarchism)" is the outward manifestation of "官僚主义(bureaucracy)". Also, it is found that another Chinese word has been relating to bureaucracy, which is "行政化 (administerization)", and there are many articles about how higher education could "deadministerization" to provide considerably free environment for its inhabitants. Sometimes it is interesting to see how insensitivity could be fed by sensitivity.

Therefore, one can observe that in terms of higher education studies, bureaucracy has different Chinese words for its divergent meanings, and the reason may be as the Soviet Encyclopedic Dictionary writes: "Bureaucracy is a specific form of social organization in society (political, economic, ideological, etc.) in which the centers of executive power are practically independent of the majority of their members." [5]

What's worth mentioning is that Max Weber has studied Chinese Bureaucracy and concluded as the "patrimonial bureaucracy (Landesvater)", which was refuted by many Chinese scholars. They believed the "rational bureaucracy" was tried and failed in Qin dynasty when legalism was practiced, therefore, the successive emperor had to choose a milder way by compensating "impersonality" with Confucianism[6].

\section{TROUBLING HIGHER EDUCATION}

Higher education is usually considered to be the Jerusalem of freedom and knowledge. Its nature is against bureaucracy. The birth of the modern university came from Europe in Middle Ages. At 
first there were just corporations of students and masters and universities had to finance themselves. Even receiving charters from popes, emperors, kings for a period of time, as part of the Enlightenment, university reform in Germany led to the concept of academic freedom, encompassing the freedom to teach and the freedom to learn, as well as the ideal of "pure knowledge" and "science". As the founder of University of Berlin Humboldt insisted that academic institution should maintain its independence from state to achieve true enlightenment and spiritual education [7].

Therefore, when government steps in, administrative power gradually take over, professors feel smothered by rules and red tapes and succumb to political power. It not only betrays the spirit they devoted since the Enlightenment but also kills creativity because their minds could hardly move in the cage.

However it was a whole different historical story in China. Even though modern universities in China were built following western regime, they are "a foreign transplant" which "conflicts with Chinese traditions".[8] Traditional higher education in China had been serving the royal authority throughout the feudal ages. Starting from later Han dynasty, Confucianism had been used and developed to consolidate the sovereign, thus ancient higher education system was designed to cultivate Confucian scholars under the instructions of government. "修身 Xiushen 齐家 Qijia 治国 Zhiguo 平 天下 Pingtianxia" (Cultivate one's moral character, put one's family affairs in order, govern the country and pacify the world) - the old motto from a classic Confucian literature 礼记-大学(The Book of Rites - Higher Education), might explain the sense of social responsibility that lies in the Chinese academic culture. For generations, Chinese literates/intellectual families cultivate their youngsters with responsibilities to bring honor to their family and country. By which, one must earn political power and lead people to a better life.

Therefore, bureaucracy is not unfamiliar to ancient Chinese higher education institutions and scholars, since they had been learning for years to strive through the hierarchies and were tested to become qualified officials for the state [9]. The belief within Chinese elites and political culture will continually influence higher education governance no matter how time and societal form changes. Inevitably, the development of modern universities rooted in western culture finds it challenging in the context. .
The prime objectives of universities are always different for playing different roles in different societies. It is hard to deny that universities have to fulfill its responsibilities toward its major stakeholders, like the government, thus intellectuals from both worlds are trying to balance the interest conflict, being practical while pursuing pure knowledge, gaining autonomy as well as grants.

\section{ALTERNATIVES IN TWO WORLDS}

Due to the emphasis on harmony and interrelationship in Confucianism, Chinese intellectuals have a practical solution to bureaucracy - NEPOTISM or called Acquaintance Society [10]. As it might be well known to many of you, nepotism refers to preferential treatment given because of personal relations. But how could it solve the problem of bureaucracy? I would like to give an example.

A university decides on implementing an administrative procedure improvement activity called "get done at once" to help students and staff dealing with administration departments but the truth is it only touches the surface of higher education administration. It indeed provides better service to students but the victims of bureaucracy are usually the administrators. All this reform and revolution are wearing down the school staff again and again.

For instance, to help students "get done at once", now we need one staff to run all the departments for THE student, which means more workloads for THE staff rather than structural reform which allow students to get it done in one place.

Imagine when administrators have to deal with all the chores for every students who keep texting you 24 hours and might get complain letters if not serve the customers right. How could they enjoy their work and be nice with each other?

These pressures could only be lightened by having a good private relation with relevant departments. It accelerates the procedures and help attaining resources. Instead of running to the financial department to wait in line for a whole day, I could just get my reimbursement papers photoed and sent to my friends there and ask him or her to print out for me. Of course whenever needed, I will do the same. This is known as the acquaintance society or a patron- client bond in China which 
somehow function as the lubricant in layered structure.

Meanwhile the West has its own solution managerialism [11]. People are wondering why higher education system cannot work like a department store and run efficiently like a cheese factory. Economists started to introduce business management models to the academic organization. It certainly worth applauds to try trans-disciplined method especially when higher education system starts to embrace the market and treat students like customers, but some might argue that academics are not going to buy the "Jack Welch' incentive packages. Intellectuals are not often external motivated, which is negotiable, who are not being whipped to be productive. Moreover, endless rules and procedures are deemed as waste of time when researchers have their own priorities.

Bureaucracy is defined as uncertainty by Gyorgy Gadjuschek [12]. According to the solutions human beings have come up with, it appears to be uncertainty that people are assuming. They use familiar connections and rules to resist it. We can see the cultural roots of the two choices. When Chinese society values family and harmonious relationships, the western world upholds rationalism. However, defects of both are easy to deduct.

When nepotism was chosen, to begin with, people became reluctant to change. Apparently, changing means they have to build new relations which is consuming and old relations could lose its magic which is a waste of all the resources that one has put into. Additionally, it is difficult to establish organizations. Any kind of reform could be difficult to put into practice as many opponents exist to pull strings. The worst situation is that the chain of corruption could be formed and conflicts of interests could lead the organization to a state of paralyze.

On the other hand, when managerialism came to the stage, alienation is the obvious consequence [13]. There are people who play the marketing rules well and those do not. And those who play well will gain their first bucket (fame, title, etc.), complete the capital accumulation (funding, equipment, etc.), resources (like students) will come to these minorities automatically, making the rich richer and the poor poorer. Inequality is the last thing you want in human resource management, especially in higher education. When the poor forced to accomplish their KPI and compromise quality, the rich try to avoid responsibility, because they have their precious reputation to protect. Then there comes research and suggestions about accountability or governance in higher education [14].

It seems universities have to take their social responsibilities like profitable institutions. There was a time when we only need to be account for knowledge and truth but now we are expecting to cultivate human resource to make profits to earn reputation to compete with each other. Why? The governments and societies are all brainwashed by the economic rules and want their investment and taxes spent "wisely", with higher earnings ratio and shorter recover phase. Contractual spirits told us to ask for return, however, was the pursuit of deeper understanding of the world and ourselves motivated by its results rather than the curiosities implanted within us? Did death sentence stop Socrates ask questions? Universities seem to forget its "初心" (the original intention) - why they are existed by the first place, as the result of neoliberalism.

How does it help us to explain the bureaucracy to some extent?

\section{CONCLUSION}

Through looking into the etymology of "bureaucracy", it can be found that Weber's definition seems to secede from the original meaning of "bureaucracy", and the debates on the definition around "bureaucracy" after that never come to an end.

Secondly, comparison between the Chinese and the West illustrates the historic culture behind bureaucracy, especially in higher educational context, which leads to different attitudes and solutions.

Finally, there is a possibility that we are mistaking the tools as the goals. No matter the red tapes or nepotism, there are tools being used to cope with bureaucracy. However, as soaking in certain kind of "corporate culture" for too long, people might forget why they are using these tools at first place, leading to abuse of personnel relations or formalism.

\section{AUTHORS' CONTRIBUTIONS}

This paper is independently completed by Chenqi Liu. 


\section{REFERENCES}

[1] "Bureaucracy." Dictionary, https://www.merriamwebster.com/dictionary/bureaucracy. Accessed 29 Jan. 2021

[2] Weber, Max. [1947] 2012. The Theory of Social and Economic Organization. Martino Fine Books.

[3] Merton, Robert K. [1957] 1968. "Bureaucratic Structure and Personality" in Social Theory and Social Structure. Glencoe, IL: Free Press. ISBN 0029211301

[4] Bureaucracy. (2017, April 30). New World Encyclopedia.

From https://www.newworldencyclopedia.org/p/ind ex.php?title=Bureaucracy\&oldid $=1004609$

[5] Vladimir Shubkin (1989) Bureaucracy, Soviet Sociology, 28(3), 27-61

[6] Gu Yu, Fang Zheng (2007) Analysis on the bureaucratic system and its spirit in ancient China, Journal of Yunnan Administration College, 2, 35-38

[7] Britannica, The Editors of Encyclopaedia. "University". Encyclopedia Britannica, 27 Apr. 2020 , https://www.britannica.com/topic/university. Accessed 1 February 2021.

[8] Yang Rui (2011) Educational research in Confucian cultural contexts: reflections on methodology, Comparative Education, 47(3), 395-405

[9] YANG Rui (2020) Political Culture and Higher Education Governance in Chinese Societies: Some Reflections

[10] HU Juan.(2019) Acquaintance Society, Bureaucracy and University Governance in China . Journal of Higher Education, 40 (2), 10-17

[11] Tony Bush, (2019) Distributed leadership and bureaucracy: Changing fashions in educational leadership, Educational Management Administration \& Leadership, 47(1), 3-4

[12] Gyorgy Gadjuschek (2003) Bureaucracy Is It Efficient Is It Not Is That The Question
Uncertainty Reduction An Ignored Element of Bureaucratic Rationality, Administration \& Society, 34,700-723

[13] Frank Parker \& David Thornton, The growth of bureaucracy and alienation in colleges of higher education, research in education, 36, 47-57

[14] Mark Murphy (2009) Bureaucracy and its limits: accountability and rationality in higher education, British Journal of Sociology of Education, 30(6), 683-695 